\title{
STRATEGI MEMBACA NYARING DI SEKOLAH DASAR
}

\author{
Luh Ketut Sri Widhiasih dan Putu Ayu Paramita Dharmayanti \\ Fakultas Keguruan dan Ilmu Pendidikan, Universitas Mahasaraswati Denpasar \\ sriwidhiasih@gmail.com dan meetmoet@gmail.com
}

\begin{abstract}
The low reading skills of students in Indonesia compared to the International encourages the government to issue a strategic policies that seek to build a love of the Indonesian people to read. At the level of the school, teachers as an executor of a policy use various strategies to improve reading comprehension of their students. One of the strategies used is reading aloud strategy. The implementation of reading aloud strategy in schools is often misunderstood, so it requires a clearer understanding of what it is reading aloud strategy and how its implementation. Reading aloud strategy is not just a way to teach reading but also a way to build a love of reading value. Love reading value character is important to get more attention in the middle of the decline of reading comprehension level of Indonesian students in the world level which can also affect the development of the country.
\end{abstract}

Keywords: Reading Aloud Strategy, Elementary School, Reading Comprehension

\section{PENDAHULUAN}

Berdasarkan hasil penelitian benchmark internasional PIRLS 2011 tentang kemampuan membaca siswa sekolah dasar kelas empat yang diadakan di banyak negara di dunia setiap lima tahun sekali, ditemukan bahwa kemampuan membaca siswa Indonesia secara umum berada pada level rendah bahkan di bawah median internasional (Kemendikbud, 2011). Namun, jika dibandingkan dengan data penelitian lima tahun sebelumnya, terjadi peningkatan kemampuan siswa pada tahun 2011 walaupun tidak signifikan. Penelitian tahun 2011 menemukan bahwa kemampuan mengulang informasi tertulis, membuat referensi, menafsir dan memadukan gagasan dan informasi, serta memeriksa dan menilai isi bahasa, dan unsur-unsur yang terdapat dalam teks masih berada dalam level rendah dibandingkan dengan rata-rata internasional. Berdasarkan analisis penelitian yang sama ditemukan salah satu faktor rendahnya kemampuan membaca siswa Indonesia adalah karena kebiasaan membaca belum dikembangkan secara memadai.

Kebiasaan membaca masyarakat Indonesia yang rendah, sudah disadari oleh pemimpin-pemimpin Indonesia terdahulu hingga sekarang, sehingga dibuatlah kebijakan agar masyarakat semakin memupuk kebiasaan membaca dan menjadikannya sebagai bagian dari tradisi. Sebut saja Presiden Soekarno yang pada pertengahan tahun 1960-an menghimbau agar segenap bangsa Indonesia membiasakan diri membaca agar dapat menambah ilmu pengetahuan. Disusul dengan Presiden Soeharto yang mengeluarkan kebijakan bahwa bulan September adalah Bulan Gemar Membaca dan tanggal 14 September 
dipilih sebagai Hari Kunjungan Perpustakaan. Pada tanggal 31 Mei 1996 di Istana Negara Jakarta diresmikan juga Perhimpunan Masyarakat Gemar Membaca (PMGM). Kebijakan-kebijakan ini bertujuan agar masyarakat Indonesia lebih memberikan perhatian pada membaca sebagai suatu unsur dari budaya bangsa. Pada era Presiden Megawati, pada tanggal 12 November 2003, Ibu Presiden menyerukan kepada seluruh komponen bangsa untuk ikut mensukseskan Gerakan Membaca Nasional. Terakhir pada masa pemerintahan Presiden Susilo Bambang Yudoyono, dicanangkan pula Gerakan Pemberdayaan Perpustakaan di Masyarakat tanggal 17 Mei 2006.

Melihat kebijakan-kebijakan yang dikeluarkan oleh pemerintah disana jelas tersirat perhatian pemerintah terhadap hasil-hasil penelitian tentang kemampuan membaca masyarakat Indonesia yang rendah. Namun, semua kebijakan itu hanya berhenti pada tataran pemerintahan dan belum mendapatkan perhatian yang serius dari masyarakat yang menjadi target dari kebijakan-kebijakan itu. Alhasil, hingga kini tingkat kemampuan membaca masyarakat Indonesia selalu berada pada tingkat rendah.

Bergeser dari kebijakan pemerintah kepada aplikasinya di sekolah, terdapat banyak strategi yang muncul dan berkembang dengan tujuan peningkaatan kemampuan membaca siswa. Salah satu strategi yang digunakan untuk meningkatkan kemampuan membaca siswa adalah strategi membaca nyaring. Strategi membaca nyaring sangat sering diaplikasikan pada pendidikan tingkat dasar di Indonesia. Namun, sering terjadi kesalahan dalam implementasi strategi ini. Guru hanya memandang strategi ini sebagai strategi dimana siswa melafalkan wacana secara oral dengan volume membaca yang lebih tinggi dari biasanya. Padahal strategi membaca nyaring tidak berhenti pada tatanan aktivitas membaca dengan suara yang keras.

Banyak hal yang bisa dipelajari dari sebuah strategi pembelajaran bernama membaca nyaring. Selain gunanya sebagai sebuah strategi membaca, strategi ini juga mengandung unsur yang membantu siswa mengembangkan karakternya sebagai manusia, yaitu nilai karakter gemar membaca. Seperti yang disampaikan pemerintah tentang nilainilai karakter yang wajib disematkan dalam pendidikan di Indonesia, karakter gemar membaca seharusnya mendapat perhatian khusus karena membaca adalah kunci dari berkembangnya peradaban sebuah bangsa. Seperti yang dinyatakan oleh Suryaman (2001) bahwa bangsa yang literasi masyarakatnya masih rendah akan mengalami peradaban yang suram. Dinyatakan lagi bahwa, bangsa yang memiliki literasi rendah adalah bangsa yang pertama kali akan jatuh dalam perkembangan peradaban. Jadi, membangun minat baca sebuah masyarakat harus menjadi prioritas utama sebuah bangsa, jika tidak bangsa itu akan segera dikuasai oleh bangsa-bangsa dengan tingkat literasi tinggi. Adapun ciri dari masyarakat literal adalah memiliki kemauan dan kemampuan untuk membaca.

\section{PEMBAHASAN}

STRATEGI

NYARING

MEMBACA 
Membaca pada hakikatnya adalah suatu aktivitas yang rumit dimana dalam aktivitas ini melibatkan banyak hal, tidak hanya sekedar melafalkan tulisan, tetapi juga melibatkan aktivitas visual, berpikir, psikolinguistik, dan metakognitif. Sebagai proses visual membaca merupakan proses menerjemahkan symbol tulis (huruf) ke dalam katakata lisan (Rahim, 2009). Pada tataran berpikir, psikolinguistik, dan metakognitif, membaca adalah aktifitas mengertikan simbol/ tulisan pada tingkatan makna yang sesuai konteks kemudian merespon apa yang dibaca melalui aktivitas lain seperti berbicara atau menulis.

$$
\text { Berdasarkan Beltchenko }
$$

(2011), membaca nyaring adalah sebuah strategi dimana seorang guru mengatur waktu untuk membaca secara oral pada siswa secara konsisten di atas tingkat membaca mandiri siswa tetapi pada tingkat mendengarkan siswa. Disebutkan juga bahwa membaca nyaring dapat digunakan sebagai aktivitas untuk memulai pelajaran, mendukung proses menulis, membantu siswa berbicara dan berpikir mengenai wacana, memperkenalkan hal baru, membiasakan siswa dengan stuktur wacana dan jenis wacana, dan mengarahkan siswa pada proses berpikir tingkat mahir.

Dikutip dari Trelease (2006) bahwa aktivitas terpenting untuk membangun pengetahuan yang membantu anak untuk sukses dalam membaca adalah membaca nyaring untuk anak-anak. Jadi dapat diartikan bahwa strategi membaca nyaring sangat tepat untuk diaplikasikan sejak dari jenjang pendidikan dini karena dapat menanamkan pondasi membaca pada anak sehingga untuk selanjutnya
http://ejournal.ihdn.ac.id/index.php/AW

kemampuan membaca anak akan terbangun dengan baik. Walaupun tidak dapat dipungkiri bahwa strategi ini juga dapat diaplikasikan pada tingkat pendidikan menengah dan tinggi. Dikuatkan kembali oleh Trealease (2006) bahwa aktivitas membaca nyaring harus terus dilanjutkan disetiap tingkat pendidikan siswa. Hal ini agar menjaga iklim membaca yang terus-menerus dan berkesinambuangan. Jadi siswa akan menjadi pembaca sepanjang hayat (membaca untuk mendidik dirinya sepanjang hidupnya) bukan hanya menjadi pembaca saat di sekolah saja (membaca hanya untuk lulus ujian membaca).

Bahan bacaan pada strategi membaca nyaring ini bisa bervariasi dari jenis bacaan fiksi, artikel majalah atau koran hingga bacaan non-fiksi. Jenis wacana yang dibacakan sebaiknya yang memiliki tingkat kesulitan di atas tingkat membaca mandiri siswa dan pada tingkat mendengarkan siswa. Hal ini bertujuan agar wacana yang dibacakan tidak terlalu mudah atau tidak juga terlalu susah untuk dimengerti. Lebih jauh, membaca nyaring tidak hanya sekedar membacakan sebuah wacana dengan lantang di depan kelas tetapi juga memerlukan proses berpikir kritis yang harus dilakukan sebelum, saat, dan sesudah membaca nyaring tersebut. Proses berpikir kritis ini terlatih melalu aktivitas-aktivitas yang diimplementasikan dalam membaca nyaring ini, seperti melakukan prediksi dan diskusi.

Duursma (2008) menyatakan bahwa membaca nyaring untuk anak atau membagikan buku bacaan telah dikaitkan dengan kedaruratan kemampuan membaca pada anak. Ini dapat diartikan bahwa strategi 
membaca nyaring sangat tepat bagi negara-negara yang memiliki tingkat literasi rendah seperti Indonesia karena dengan tingkat literasi rendah ini maka dipandang darurat untuk segera ditingkat kemampuan membacanya dengan memberikan model membaca yang baik melalu strategi membaca nyaring oleh guru. Kemampuan membaca ini harus ditangani terlebih dahulu sebelum akhirnya siswa mempelajari kemampuan yang lebih tinggi, karena dengan kemampun membaca yang rendah agak mustahil bagi seseorang untuk dapat memahami ilmu yang lebih tinggi dengan baik.

Membaca nyaring memberikan kesempatan pada guru untuk memberikan model cara membaca yang lancar dan membaca ekspresif. Pada tingkat awal, siswa masih memerlukan contoh atau model bagaimana cara membaca yang baik, misalnya bagaimana melafalkan sebuah kata, memberikan penekanan pada kata atau kalimat, dan menentukan jeda. Untuk memberikan pemahaman pada isi bacaan yang dibaca guru juga memberikan bagaimana mengekspresikan isi wacana dengan pengaturan ritme, intonasi, volume dan kecepatan dalam membaca. Dengan strategi membaca nyaring seorang guru juga mendapat kesempatan untuk mengulas kembali struktur wacana, dimana seorang guru dapat memberikan penekanan pada setiap bagian dari sebuah wacana. Strategi ini memposisikan guru sebagai fasilitator, terutama untuk pembelajar pemula dan menengah karena pada tingkat ini siswa cenderung masih sangat memerlukan contoh dari gurunya. Sebagai fasilitator juga guru mendapat kesembatan untuk menyediakan beragam wacana dan dapat menghubungkan dan memberi makna wacana satu dengan yang lain (Beltchenko, 2011).

Adapun strategi membaca nyaring memiliki banyak manfaat bagi siswa sebagai pendengar. Siswa dapat meningkatkan dasar kosa kata mereka dengan cara mendengarkan kata-kata yang terkandung dalam wacana yang dibacakan oleh gurunya dan menyesuaikannya dengan konteks yang tepat. Jadi siswa tahu dalam konteks apa mereka dapat menggunakan kata-kata tertentu sehingga dapat mudah dimengerti. Dalam belajar bahasa kegiatan membaca nyaring sangat besar kontribusinya terhadap belajar berbicara (Rokayah, 2014). Melalui strategi membaca nyaring siswa belajar mengucapkan bunyi-bunyi bahasa yang dipelajarinnya dengan benar. Bahkan, siswa bukan hanya belajar mengucapkan bunyi-bunyi bahasa yang dipelajarinya, tetapi juga belajar mengucapkan kelompok kata, kalimat, dan bahkan

mengucapkan suatau wacana utuh dengan benar melalui membaca nyaring.

Siswa dapat membangun kemampuan mendengar dan pemahamannya dalam sesi diskusi sebelum, selama dan setelah gurunya membaca nyaring. Kemampuan mendengarkan disini sangat diperlukan sehingga dapat mengertikan kemudian mendiskusikan isu-isu penting dalam wacana. Selanjutnya, siswa dapat mendengarkan contoh kelancaran, suara, drama dan kemenarikan dari sebuah wacana tertulis yang dituangkan dalam bahasa lisan dengan ketelatenan gurunya yang sangat menikmati dunia kesusastraan. Hal ini 
dimaksudkan dimana siswa tidak hanya mempelajari makna dari sebuah wacana tetapi juga dapat menikmati sisi keindahan dari wacana yang dibalut dalam sastra lisan oleh gurunya.

Rukoyah (2014) dalam
penelitiannya tentang pengaruh
metode membaca nyaring terhadap pemahaman bacaan siswa kelas dua madrasah ibtidayah menyatakan bahwa pemahaman siswa dalam membaca yang diajarkan dengan menggunakan strategi membaca nyaring lebih baik daripada yang menggunakan metode pembelajaran konvensional. Pada level pendidikan yang lebih tinggi, Widhiasih dan Wahyudi (2016) yang mengadakan penelitian deskriptif tentang aplikasi strategi membaca nyaring pada tingkat universitas. Hasilnya menunjukkan bahwa strategi ini dapat memperkaya kosakata dan pelafalan siswa, mengembangkan pemahaman siswa terhadap struktur wacana, mendorong pemahaman tingkat tinggi, membuat siswa belajar pada konteks yang bermakna, dan membuat siswa memiliki motivasi dalam membaca. Dari kedua penelitian terdahulu tersebut dapat disimpulkan bahwa strategi membaca nyaring dapat digunakan di segala jenjang pendidikan dan manfaat serta keunggulannya dalam mengajarkan membaca pada siswa tidak dipengaruhi oleh tempatnya diaplikasikan.

\section{IMPLEMENTASI STRATEGI MEMBACA NYARING DI SEKOLAH DASAR}

Seperti yang dinyatakan pada pembahasan sebelumnya bahwa strategi membaca nyaring dapat diimplementasikan pada semua tingkatan pendidikan. Namun, kembali ditegaskan bahwa strategi membaca nyaring lebih tepat digunakan pada jenjang pendidikan dini atau dasar, seperti sekolah dasar; karena pada tingkat ini siswa memerlukan model dalam membaca. Berikut disajikan langkah-langkah yang dapat digunakan dalam pengimplementasian strategi membaca nyaring di sekolah dasar. Langkah-langkah tersebut di bawah diadaptasi dari strategi membaca nyaring yang dirumuskan oleh Beltchenko (2011).

Sebelum memulai implementasi dari strategi membaca nyaring ini, ada baiknya seorang guru melakukan beberapa persiapan. Pertama yaitu menentukan tujuan pembelajaran membaca tersebut sehingga jelas hal apa yang ingin dicapai setelah pembelajaran itu selesai. Kemudian, seorang guru harus memilih teks yang membantu guru mencapai tujuan pembelajaran. Perlu diingat bahwa wacana yang baik digunakan dalam strategi membaca adalah wacana yang memiliki tingkat kesulitan di atas tingkat membaca mandiri siswa dan pada tingkat mendengarkan siswa.

Setelah itu, guru hendaknya mengidentifikasi proses yang harus dilakukan berkaitan dengan strategi membaca nyaring seperti dengan cara menyusun

langkah-langkah pembelajaran. Bilamana topik yang akan dibaca adalah hal yang baru, ada baiknya guru mengantisipasi cara untuk membangun pemahaman awal siswa sebelum kegiatan membaca dimulai. Berikutnya, guru harus terlebih dahulu membaca wacana yang akan dibacakan nyaring dan menandai wacana (dimana harus memberi jeda, bertanya, membuat prediksi, dan atau membuat hubungan yang berkaitan 
dengan wacana). Hal ini dilakukan agar guru tidak melakukan kesalahan dalam prakteknya nanti.

Berikutnya, menyiapkan pertanyaan untuk sesi diskusi menjadi penting untuk dipersiapkan mengingat dalam sesi diskusi ini pemahaman siswa akan apa yang dibacakan diuji. Hal lain, seorang guru walaupun sudah terkategori professional dalam bidangnya tetap harus melatih caranya membaca wacana yang akan dibacakan nyaring di depan siswa dengan menggunakan gerakan dan intonasi yang tepat; hal ini untuk memantapkan diri guru ketika memberi contoh di depan kelas. Menjadi kewajiban seorang guru untuk membuat rencana pembelajaran sebelum, selama, dan sesudah aktivitas membaca untuk meningkatkan pemahaman serta membuat pembelajran ada pada rel yang benar.

Setelah proses persiapan, saatnya guru mengeksekusi apa yang sudah direncanakannya. Pada kegiatan awal sebelum memulai membaca, guru dapat membuka pertemuan dengan menginformasikan tujuan pembelajaran kemudian disusul dengan membicarakan sesuatu yang berkaitan dengan topic wacana. Kemudian guru dapat membagikan wacana yang akan dibaca untuk selanjutnya menginstrusikan siswa untuk mengidentifikasi penulis, judul, setting, dan karakter yang ada dalam wacana. Guru dapat mengingatkan siswa kembali pada pengetahuan terdahulu yang berkaitan dengan wacana tersebut. Guru juga dapat melengkapi dirinya dengan media pembelajaran seperti gambar atau ilustrasi. Kemudian sebelum mulai membaca, guru mengajak siswa untuk memprediksi, membandingkan, menghubungkan, memberikan komentar, dan mengevaluasi isi atau jalan cerita dari wacana yang akan dibaca. Aktivitas ini dapat meningkatkan daya imajinasi siswa tentang wacana tersebut dan dapat meningkatkan rasa keingintahuan siswa terhadap wacana yang akan dibaca.

Menuju ke inti kegiatan, guru dapat melakukan membaca nyaring dengan sesekali tetap berinteraksi dengan siswa dengan meminta respon siswa terhadap kalimat yang dibacakan. Sesekali munculkan dialog antar siswa dan guru dan juga antara siswa dan siswa tentang setiap kalimat yang mereka dengarkan. Guru juga harus membuka kesempatan bagi siswa untuk membagikan pengalamannya berkaitan dengan wacana. Jika terdapat pertanyaan di tengah-tengah pembacaan sebaiknya guru menrespon atau menjawab pertanyaan, berikan kesempatan merespon dari pihak siswa terlebih dahulu kemudian guru hanya menyimpulkan atau menambahkan saja. Guru juga sebaiknya tidak membatasi pertanyaan siswa pada sebatas pertanyaan benar dan salah atau iya dan tidak saja tetapi juga pada pertanyaan yang memungkinkan sebuah diskusi terjadi. Sebagai media guru dapat menggunakan story map atau peta cerita sehingga walaupun terjadi diskusi cerita yang dibacakan masih ada pada jalur yang benar.

Pada kegiatan akhir, guru dapat meminta respon siswa terhadap wacana tadi. Kemudian untuk mengecek apakah siswa mengikuti alur cerita yang dibacakan, guru dapat meminta siswa untul menceritakan kembali dengan menggunakan format lini masa. Guru juga dapat mengarahkan siswa untuk menyimpulkan cerita dan membagikan 
pemahamannya terhadap wacana sekaligus melakukan pengecekan terhadap prediksi yang dilakukan di awal pembelajaran sebelumnya. Pada langkah pembelajaran ini siswa akan membuktikan ketepatannya dalam memprediksi sebuah cerita dan semakin tertantang untuk memprediksikan cerita-cerita berikutnya.

\section{NILAI KARAKTER DALAM STRATEGI NYARING MEMBACA}

Di Indonesia, pendidikan karakter telah menjadi isu yang mengemuka sejak tahun 2011. Pendidikan karakter atau penyelipan nilai karakter dalam pendidikan pertama kali diumumkan oleh Pemerintah Indonesia pada tahun 2011. Hal ini terpicu oleh banyaknya kasus-kasus kenakalan yang dilakukan oleh remaja. Kenakalan remaja ini mengambil bentuk seperti tawuran antar pelajar dan perilaku seks bebas oleh remaja. Kenakalan remaja ini berusaha dicari penyebabnya oleh pemerintah. Hingga akhirnya pemerintah merumuskan bahwa kurikulum pendidikan Indonesia harus mengandung unsur nilai-nilai kharakter. Hal ini diharapkan dapat mengurangi permasalahan kenakalan remaja yang semakin meningkat.

Pemerintah menyatakan ada 18 nilai-nilai pendidikan karakter yang harus dimasukkan dalam pendidikan Indonesia. Nilai-nilai pendidikan karakter tersebut adalah nilai religius, kejujuran, toleransi, disiplin, kerja keras, kreativitas, kemandirian, demokrasi, komunikatif, rasa ingin tahu, nasionalisme, cinta tanah air, menghargai prestasi, kesadaran sosial, kesadaran lingkungan, perdamaian, tanggung jawab dan gemar membaca ( Kemendiknas, 2011).

Sebelum pemerintah Indonesia mengumumkan nilai-nilai tersebut dalam pendidikan karakter, negaranegara lain sudah menjadikan nilai karakter sebagai perhatian utama dalam pendidikan mereka. Secara informal, pendidikan karakter sudah ditanamkan di setiap tradisi dan budaya Indonesia tetapi karena era globalisasi yang membawa beberapa efek pada gaya hidup anak muda Indonesia yang cenderung negatif, maka pendidikan karakter dirasa perlu dinyatakan secara resmi dan tertulis dalam kurikulum pendidikan Indonesia. Berbicara tentang karakter, orang berpikir bahwa itu hanya terbentuk ketika orang masih muda dan mengabaikan hal itu ketika mereka semakin tua. Karakter harus konsisten dibangun dalam kehidupan manusia dalam pendidikan formal atau informal dan sejak usia dini hingga dewasa.

Pembangunan karakter sejak dini bisa ditanamkan sejak jenjang pendidik formal sekolah dasar. Di sekolah, siswa disajikan berbagai aktivitas di dalam maupun di luar kelas yang secara tidak disadari dapat menanamkan nilai karakter dalam diri siswa sedari dini. Salah satu nilai karakter yang harus dibangun sejak dini sehingga menjadi tradisi adalah nilai karakter gemar membaca. Seperti yang ditunjukkan oleh data tentang tingkat literasi internasional oleh Central Connectut State University (2016), tingkat literasi Indonesia adalah pada rangking 60 dari 61 negara. Di negara lain, orang membaca setidaknya 12 buku dalam satu tahun, tetapi di Indonesia orang bahkan tidak membaca satu buku pun 
dalam satu tahun. Orang Indonesia hanya membaca halaman-halaman yang dirasa penting dalam sebuah buku, mereka tidak membaca keseluruhan isi buku tersebut. Data ini menunjukkan tingkat literasi yang rendah di Indonesia. Hal ini menjadi perhatian bagi pemerintah untuk meningkatkan kemampuan itu karena membaca adalah keterampilan penting untuk mendukung keterampilan lainnya. Tanpa membaca orang akan terjebak dan tidak bisa memperbaiki diri atau bahkan bersaing di era global ini.

\begin{tabular}{ll}
\multicolumn{2}{c}{ Pemilihan stategi dalam } \\
pengajaran membaca untuk
\end{tabular}
meningkatkan kemampuan membaca dan menanamkan budaya membaca juga harus memperhatikan apakah strategi itu dapat membangun nilainilai karakter yang disyaratkan oleh pemerintah untuk ada dalam setiap langkah pembelajaran. Strategi membaca nyaring sebagai salah satu strategi pembelajaran membaca juga dapat membantu penanaman nilai karakter pada diri siswa. Nilai karakter utama yang dibangun melalui strategi ini adalah nilai karakter gemar membaca. Menurut Widhiasih (2016), strategi membaca nyaring membawa lingkungan bermakna dan kontekstual untuk membaca. Kondisi yang tidak hanya membuat siswa memahami dengan baik teks tetapi juga membangun kemauan siswa untuk membaca sehingga siswa gemar membaca. Gemar membaca tidak hanya penting dalam hal pembelajaran bahasa tetapi karakter ini juga akan mendukung mata pelajaran lain (Suryaman, 2010). Suryaman (2010) juga menambahkan bahwa membaca juga bisa meningkatkan pemahaman tentang manusia dan kemanusiaan, memperkenalkan kepada nilai-nilai, mendapatkan ide-ide, dan menambah pengetahuan tentang sosial budaya, menumbuhkan perasaan dan kreativitas, dan juga membangun karakter dan kepribadian.

Aplikasi langsung dari strategi membaca nyaring dapat juga membangun beberapa nilai-nilai pendidikan karakter, seperti toleran, rasa ingin tahu, kreativitas, komunikatif, bertanggung jawab, kerja keras, gemar membaca, disiplin, dan demokratis tetapi secara tidak langsung dari strategi membaca nyaring dapat membangun semua nilai-nilai pendidikan karakter melalui pesan moral yang disisipkan di setiap wacana yang dibaca oleh pembaca (Widhiasih, 2016). Nilai toleran dapat dibangun saat siswa dibimbing untuk mau mendengarkan wacana yang sedang dibacakan. Pada tingkat pendidikan dasar, penanaman nilai karakter toleransi memang agak susah karena pembelajar masih sangat belia dan karakter yang ada dalam diri siswa masih terus tumbuh dan berkembang. Namun, dengan kesabaran dan ketelatenan yang guru miliki maka nilai tersebut akan mudah ditanamkan.

Berikutnya, karakter rasa ingin tahu siswa juga terbangun dengan aplikasi strategi membaca nyaring. Khususnya, karakter ini terbangun saat siswa diminta untuk melakukan prediksi terhadap wacana yang akan dibacakan di awal. Di akhir pembacaan wacana, rasa ingin tahu siswa terhadap isi wacana akhirnya terjawab. Kreativitas dari siswa juga terbangun saat siswa diminta untuk memprediksi isi wacana. Disana siswa akan mengembangkan kreativitas abstraknya dalam bentuk imajinasi tentang apa yang akan terjadi terhadap karakter pada wacana tersebut. Nilai karakter komunikatif terbangun 
sepanjang pengaplikasian strategi membaca nyaring karena sejatinya stategi ini sangat berfokus pada interaksi antar siswa; guru hanya berperan sebagai fasilitator.

Nilai disiplin juga dapat dilatih dalam penginplementasian strategi membaca nyaring. Hal ini dapat diwujudkan dengan cara membimbing siswa untuk mengikuti setiap langkah pembelajaran dalam strategi ini secara disiplin. Sesi diskusi dalam strategi membaca nyaring juga dapat memupuk nilai demokratis karena siswa dapat dilatih untuk dapat menerima pendapat orang lain dan dapat mengemukakan pendapatnya yang mungkin berbeda dengan siswa lainnya. Saat sesi diskusi siswa juga terlatih untuk menggunakan daya pikir kritisnya untuk merespon setiap isu yang dibahas dalam diskusi tersebut.

\section{SIMPULAN}

Strategi membaca nyaring menjawab kebutuhan siswa terhadap sebuah strategi yang tidak hanya membantu siswa untuk meningkatkan kemampuan membacanya tetapi juga dapat membangun karakter siswa. Jadi strategi membaca nyaring bukan hanya strategi yang dapat digunakan untuk mengajarkan pemahaman membaca pada siswa tetapi juga sebuah trategi yang dapat membangun karakter siswa sejak dini. Pengaplikasian dari strategi ini juga sudah berfokus pada siswa. Jadi siswa yang lebih aktif melakukan kegiatan diskusi dan merespon selama pembelajaran membaca berlangsung; sedangkan guru hanya sebagai fasilitator.

Disarankan bagi para guru yang mengajarkan pemahaman membaca di sekolah dasar khususnya untuk menggunakan strategi membaca nyaring mengingat strategi ini tidak hanya berfokus pada kemampuan membaca tetapi juga pada nilai karakter.

\section{DAFTAR PUSTAKA}

Beltchenko, Laura. (2011). The Components of Effective Read Alouds. Chicago Literacy Project

Duursma, E., Augustyn, M., and Zuckerman, B. (2008). Reading Aloud to Children: The Evidence. An Article in Arch Dis Child Vol 93 No 7

Trelease, Jim. (2006). The Read-Aloud Handbook. New York: Penguin Putnam.

Kemendikbud, Litbang. (2011). Kemampuan Membaca Siswa Indonesia di Dunia. Jakarta: Litbang Kemendikbud.

Kemendiknas. (2011). Panduan Pelaksanaan Pendidikan Karakter. Badan Penelitian dan Pengembangan Pusat Kurikulum dan Perbukuan. Jakarta.

Rahim, Farida. (2009). Pengajaran

Membaca di Sekolah Dasar. Bumi Aksara: Jakarta.

Rukoyah, Siti. (2014). Pengaruh Metode Reading Aloud (Membaca Nyaring) Terhadap Pemahaman Bacaan Siswa Kelas II MI Nurul Huda Curug Wetan Tangerang Tahun Pelajaran 2013/2014. Universitas Islam Negeri Syarrif Hidayatulah. Jakarta. 
Skripsi yang tidak http://ejournal.ihdn.ac.id/index.php/AW dipublikasikan.

Natalis of UNY Special Edition.

Suryaman, M. (2001) Kesiapan Masyarakat Sunda Menghadapi Era Global, Makalah pada Konfrensi Internasional Budaya Sunda (The Indonesian Conference on Sundanese Culture), Gedung Merede, Bandung, 2225 Agustus 2001

Suryaman, Maman. (2010). Pendidikan Karakter melalui Pendidikan Sastra. An Article in Cakrawala Pendidikan Journal. Th. XXIX, Dies

Widhiasih, Luh Ketut Sri and Wahyudi, Nyoman Deni. (2016). Strategi Membaca Nyaring Pada Kelas Membaca Mahir. Sebuah artikel yang dipresentasikn pada Seminar Nasional Universitas Mahasaraswati Denpasar 2016.

Widhiasih, Luh Ketut Sri. (2016). Character Education in the Application of Reading Aloud Strategy. Sebuah Artikel yang presentasikan dalam DAFIS 2016 